\title{
Article
}

\section{Maritime Enforcement of United Nations Security Council Resolutions: Use of Force and Coercive Measures}

\author{
Zou, Keyuan
}

Available at http://clok.uclan.ac.uk/4919/

Zou, Keyuan ORCID: 0000-0002-2868-4948 (2011) Maritime Enforcement of United Nations Security Council Resolutions: Use of Force and Coercive Measures. International Journal of Marine and Coastal Law, 26 (2). pp. 235261. ISSN 0927-3522

It is advisable to refer to the publisher's version if you intend to cite from the work. http://dx.doi.org/10.1163/157180811X560502

For more information about UCLan's research in this area go to http://www.uclan.ac.uk/researchgroups/ and search for <name of research Group>.

For information about Research generally at UCLan please go to http://www.uclan.ac.uk/research/

All outputs in CLoK are protected by Intellectual Property Rights law, including Copyright law. Copyright, IPR and Moral Rights for the works on this site are retained by the individual authors and/or other copyright owners. Terms and conditions for use of this material are defined in the policies page.

\section{CLoK}

Central Lancashire online Knowledge www.clok.uclan.ac.uk

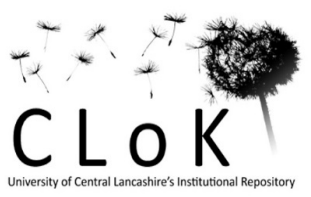




\title{
Maritime Enforcement of United Nations Security Council Resolutions: Use of Force and Coercive Measures
}

\author{
ZOU Keyuan \\ Harris Professor of International Law, Lancashire Law School, \\ University of Central Lancashire, Preston PR1 2HE, UK
}

Received: 20 July 2010; revised: 20 October 2010; accepted: 1 November 2010

\begin{abstract}
The Charter of the United Nations designates the United Nations Security Council (UNSC) as one of the principal organs of the United Nations, assuming the "primary responsibility for the maintenance of international peace and security". It has the power to determine the existence of any threat to the peace, breach of the peace, or act of aggression, to make recommendations, and decide what measures should be taken to maintain or restore international peace and security. This article addresses a number of issues concerning how the UNSC Resolutions are enforced at sea in accordance with applicable international law and makes special reference to the circumstances in East Asia, particularly the Korean Peninsula.
\end{abstract}

\section{Keywords}

United Nations Security Council (UNSC); UNSC Resolution; maritime enforcement; law of the sea; use of force

\section{The Legal Nature of United Nations Security Council Resolutions}

The Charter of the United Nations designates the United Nations Security Council (UNSC) as one of the principal organs of the United Nations, assuming the "primary responsibility for the maintenance of international peace and security". ${ }^{2}$ It plays a key role in two major domains of international peace and security: dispute settlement and maintenance and restoration of peace and security. The second domain is addressed by the theme of this article.

\footnotetext{
' It is acknowledged that the author benefits a lot from the comments and suggestions from the anonymous reviewers of the article. However, the author assumes the sole responsibility for any error or omission in the article.

2 Article 24 (1) of the UN Charter. The whole text of the Charter is available at: http://www .un.org/en/documents/charter/index.shtml (accessed 24 January 201 1).
} 
According to the UN Charter, the UNSC has the power to "determine the existence of any threat to the peace, breach of the peace, or act of aggression and shall make recommendations, or decide what measures shall be taken"... "to maintain or restore international peace and security". ${ }^{3}$ It may decide what non-military measures, such as economic sanctions and the severance of diplomatic relations, are to be employed to give effect to its decisions, ${ }^{4}$ and take military action when the non-military measures have proved to be inadequate. "Such action may include demonstrations, blockade, and other operations by air, sea, or land forces of Members of the United Nations".

Because of the above stipulations, it is commonly accepted that UNSC Resolutions possess legally binding force, although they are not equivalent to treaties. In fact, the UNSC attempts to prepare its Resolutions more like a treaty. This can be seen in the wording and formality of its Resolutions. Take Resolution 1540 (2004) as an example. ${ }^{6}$ It concerns the proliferation of nuclear, chemical and biological weapons. The Resolution defines "means of delivery", "non-State actor", etc., uses the word "shall" - a very strong word that, due to its mandatory nature, more usually appears in treaties and lawsand intends to bind all States (not UN Members alone). ${ }^{\text {? }}$

The terminology used in UNSC Resolutions also sets the degree of their compulsory binding force. For example, the term 'decide' must be stronger than the terms such as 'require' or 'urge', which are less compelling. For that reason, when deliberations on draft Resolutions take place, UNSC members, due to their different interests and positions, usually debate very hotly which terms should be adopted for the Resolution to be passed. ${ }^{8}$

After North Korea's nuclear weapon test, the UNSC passed Resolution 1718 condemning North Korea's irresponsible act and called upon it to halt

\footnotetext{
3 Article 39 of the UN Charter.

4 See Article 41 of the UN Charter.

5 Article 42 of the UN Charter.
}

"UN Doc. S/RES/1540 (2004), adopted on 28 April 2004. 43 ILM 1237 (2004); also available at: http://daccess-dds-ny.un.org/doc/UNDOC/GEN/N04/328/43/PDF/N0432843.pd?? OpenElement (accessed 24 January 2011).

7 For example, "all States shall refrain from providing any form of support to non-State actors that attempt to develop, acquire, manufacture, possess, transport, transfer or use nuclear, chemical or biological weapons and their means of delivery"(emphasis added).

${ }^{*}$ China and Japan took very different views on draft Resolution 1695 regarding the possible sanctions to be imposed on North Korea. When Japan asked to include Chapter VII of the UN Charter, China disagreed. Regarding the prohibition of export of missile and related materials to North Korea, the Japanese draft used the term 'decide' while the Chinese used 'call on' instead. As a result, the final version of the Resolution uses the term 'require' as a compromise. 
this action. ${ }^{9}$ This Resolution has been discussed in the international legal circle, because it is regarded as containing "several uncommon provisions". ${ }^{10}$

Unlike the two previous Resolutions on the DPRK [North Korea], which had not explicitly referred to Chapter VII, the new Resolution contains provisions legally binding the DPRK and UN member States. ${ }^{11}$

Thus, Resolution 1718 is "unique in going beyond the detailed obligations imposed on Iraq in resolution 687 (1991)". ${ }^{12}$

Because the UNSC Resolutions are unilaterally adopted to impose sanctions upon a Member State, despite the authorization from the UN Charter, the countries to be punished are usually averse to these Resolutions and respond negatively by stating that they will never accept them. This can be seen in the latest development regarding UNSC Resolution 1747 of 24 March 2007 against Iran. ${ }^{13}$ In response, Iran ceased its cooperation with the International Atomic Energy Agency (IAEA) for certain projects and pledged to continue its nuclear program. The Iranian condemnation and defiance of the UNSC Resolution no doubt has brought extreme difficulties in the effective implementation and enforcement of the Resolution, thus even qualifying its validity.

It is mentioned in the scholarly literature that the International Court of Justice (ICJ) never answered the request on the validity of the UNSC Resolutions:

in the Aerial Incident at Lockerbie it declined to question the validity of a Security Council resolution adopted under Chapter VII. In the Genocide case it refused a Bosnian request for the indication of provisional measures which would in effect have opposed the application to Bosnia of an arms embargo imposed by the Council in resolution $713(1991) .^{14}$

UNSC Resolution 1718 (2006), 14 October 2006, reprinted in 45 ILM 1237 (2006).

10 See Andreas L. Paulus and Jörn Müller, "Security Council Resolution 1718 on North Korea's Nuclear Test", 10 (29) ASIL Insight, 3 November 2006, available at: http://www.asil .org/insights061103.cfm (accessed 5 October 2010).

11 Ibid.

12 Ibid.

13 UN Doc S/RES/ 1747 (2007). The Resolution is available at: http://daccess-dds-ny.un.org/ doc/UNDOC/GEN/N07/281/40/PDF/N0728140.pdf?OpenElement (accessed 24 January 2011).

${ }^{14}$ Christopher Greenwood, "The International Court of Justice and the Use of Force", in: Vaughan Lowe and Malgosia Fitzmaurice (eds.), Fifty Years of the International Court of Justice: Essays in Honour of Sir Robert Jennings (Cambridge: Cambridge University Press, 1996) 373388 at 376. 
The superficial reason is that because the UNSC has the primary responsibility to maintain and restore peace and security around the world, it is not appropriate for the ICJ to assess, or even adjudicate the validity of UNSC Resolutions. However, it is possible to suggest that UNSC Resolutions in the past have never been really effectively implemented in practice, so that any assessment of them would definitely become a hot potato, inviting more controversies than clarification.

Even if UNSC Resolution 1718 was hailed as a milestone in resolving the North Korean nuclear issue, the substantive achievements were made not at the table of the UNSC, but through the Six-Party Talks, although Resolution 1718 did create some international pressure on North Korea. A related question concerns the duration of validity of a UNSC Resolution. Unlike a treaty, no clause in a UNSC Resolution specifies its duration of validity.

However, some Resolutions contain a designated period for a particular authorization from the UNSC. For example, Resolution 1816 concerning piracy and armed robbery in Somali waters sets a period of six months during which UN Member States are authorised to enter "the territorial waters of Somalia for the purpose of repressing acts of piracy and armed robbery at sea". ${ }^{15}$ As this period is only limited to Operative Paragraph 7 of the Resolution, it is clear that it does not refer to the duration of the validity of the whole Resolution. In the same vein, consider Resolution 1718, which is the response of the UNSC to the nuclear test undertaken by North Korea. It is unclear whether the Resolution is still valid and legally binding after the Six-Party Agreement was achieved in Beijing in 2007. ${ }^{16}$

Nevertheless, it is fair to say that the UNSC has contributed tremendously to world peace and security. The ineffectiveness of its Resolutions is not the fault of the UNSC, but rather a fault resulting from the deficiencies of our contemporary international structure, which is centred upon sovereignty of individual nation States. Without a governing body placed above individual States, the UNSC can actually only call for, instead of ordering or instructing, States, more often the UN Member States, to implement and enforce its Resolutions. In the above particular sense, the UNSC is somewhat more like a consultative body, despite the authority granted to it by the UN Charter.

15 See UNSC Resolution 1816, 2 June 2008. The text is available at: hrtp://daccess-dds-ny .un.org/doc/UNDOC/GEN/N08/361/77/PDF/N0836177.pdf?OpenElement (accessed 1 October 2010).

16 Unfortunately, the Six-Party Talks have been discontinued since April 2009, when North Korea decided to withdraw from the Talks in response to a UNSC Presidential Statement which condemned North Korea for its testing of a missile in early April that year. 


\section{Requirements for Implementation and Enforcement}

\section{The Duty of a Member State}

Once a country joins the United Nations, it is bound by the UN Charter, and to the decisions made by the UNSC, because the UN Charter provides that UN Members agree to accept and carry out the decisions of the UNSC in accordance with the Charter. ${ }^{17}$ Furthermore, UN Member States have the duty to contribute to the maintenance of international peace and security by materially supporting the actions undertaken by the UNSC, with armed forces, assistance, and facilities, including rights of passage. ${ }^{18}$ Article 45 of the UN Charter clearly provides that:

In order to enable the United Nations to take urgent military measures, Members shall hold immediately available national air-force contingents for combined international enforcement action. The strength and degree of readiness of these contingents and plans for their combined action shall be determined within the limits laid down in the special agreement or agreements referred to in Article 43, by the Security Council with the assistance of the Military Staff Committee.

Military actions can be carried out by all or some of the UN member States, as the UNSC determines. Related to the above provision is Article 43, which requires UN Member States to negotiate and conclude agreements with the UNSC regarding "the numbers and types of forces, their degree of readiness and general location, and the nature of the facilities and assistance to be provided"19 for their contributions to the maintenance of international peace and security. The history of UN peacekeeping operations indicates that not only the States within the region of conflict, but also States from other parts of the world have been involved in military actions authorised by the UNSC. However, although the United States is the biggest provider to the UN peacekeeping budgets, it is not among the top twenty countries that provide peacekeeping personnel. ${ }^{20}$

In addition to contributing to UN peacekeeping operations, UN Member States can also take other coercive measures to enforce UNSC Resolutions. For example, in response to the UNSC Resolutions on Somali piracy, about 27 countries, including five UNSC permanent Members, have sent their

17 Arricle 25 of the UN Charter.

${ }^{18}$ See Article 43 of the UN Charter.

1) Ibid.

201 See "Fact Sheet: United Nations Peacekeeping", available at: http://www.un.org/en/peacekeeping/documents/factsheet.pdf (accessed 4 October 2010). 
warships, either individually or collectively, to that sea area to protect merchant ships and humanitarian ships of the United Nations from being attacked by Somali pirates. ${ }^{21}$

Following the UNSC call, UN Member States may also take domestic measures in compliance with the UNSC requirement. After the adoption of several Resolutions by the UNSC regarding anti-terrorism and the prevention of nuclear proliferation, China revised its Regulations on the Control of Nuclear Export in November 2006. ${ }^{22}$ New purposes, such as the prevention of nuclear terrorist acts, have been added to the Regulations. ${ }^{23}$ New provisions are also added. The most significant addition is the provision that "the Recipient Government shall guarantee not to produce enriched uranium with more than $20 \%$ density with enriched uranium facilities, technology or any facility based on such technology supplied by China, without the consent of the Chinese Government". ${ }^{24}$ Meanwhile, in January 2007, China revised the Regulations on the Control of Exporting Dual-use Nuclear Items and Related Technology as a supplement to the revision of the 2006 Regulations. ${ }^{25}$

Some UN Member States tend to make specific laws or regulations to enforce the sanctions imposed by the UNSC on a State which has breached its international obligations. For example, New Zealand introduced the United Nations Sanctions (Iran) Regulations 2007 to implement UNSC Resolution 1737, which took effect from 23 March 2007, prohibiting the export to or import from Iran of items, materials, equipment and goods that could contribute to Iran's enrichment-related, reprocessing or heavy-water-related activities, or to the development of nuclear weapon delivery systems. ${ }^{26}$ Similarly, in response to UNSC Resolutions on the issue of Somali piracy, Japan promulgated the Law on the Punishment of and the Measures against Acts of Piracy in June 2009 as a domestic measure to enforce UNSC Resolutions. ${ }^{27}$ These

21 The most visible presence is the Combined Task Force 151, which is a multinational force established in January 2009 to conduct counter-piracy operations in the Gulf of Aden and off the eastern coast of Somalia. See "Combined Task Force (CTF) 151", available at: http://www .cusnc.navy. mil/cmf/151/index.html (accessed 5 October 2010).

22 The Regulations came into effect on 1 December 2006. The text is available in People's Daily (in Chinese), 2 December 2006, at 6.

${ }_{23}^{23}$ Arricle 1 of the 2006 revised Regulations.

${ }^{24}$ Article 5 (5) of the 2006 revised Regulations.

${ }^{25}$ It came into force on 26 January 2007 . The text is available at: http://www.gov.cn/zwgk/ 2007-02/16/content_529172.htm (accessed 23 March 2007).

26 See United Nations Sanctions (Iran) Regulations 2007 (SR 2007/74), available at: http:// www.legislation.govt.nz/regulation/public/2007/0074/lates/DLM431042.html (accessed 24 January 2011).

27 For relevant information, see Moritaka Hayashi, "Japan: Anti-Piracy Law"(2010) 25 (1) International Journal of Marine and Coastal Law 143-149. 
brief examples are just an illustration of how States respond positively to the UNSC Resolutions. Similar examples abound in State practice. ${ }^{28}$

Regarding the enforcement of UNSC Resolutions by domestic courts, the United States has two relevant cases: in Diggs $v$. Richardson (1976), the court held that the UNSC Resolution condemning the continued presence of South Africa in Namibia was "not self-executing" and "not self-enforcing so as to grant individually enforceable rights". ${ }^{20}$ In Diggs $v$. Shultz (1972), the court "refused to enjoin the importation of metallurgical chromite from Southern Rhodesia in violation of a United Nations Security Council resolution of 1966, in which the United States joined, and which called for a trade embargo of all that country's products". ${ }^{30}$

In comparison with the ambiguity in US courts, British judicial bodies have a more clear-cut answer regarding the validity of UNSC Resolutions, although these Resulutions are not incorporated into British law. The House of Lords recently addressed two cases. In Kuwait Airways Corp. v. Iraqi Airways Co. (2002), "the Lords invoked unincorporated Security Council resolutions, jus cogens norms and customary international law to determine the status of Iraq's actions as breaches of international law". ${ }^{31}$ The Al-jedda case (2006) shows that if there is a conflict between a provision of domestic law and a Chapter VII UNSC resolution, "UN Charter 103 required that the domestic right be overridden". 32

\section{The Maritime Factor in Enforcement}

The most important legal document in this respect is the 1982 United Nations Convention on the Law of the Sea (LOS Convention) which came into force in 1994. ${ }^{33}$ The LOS Convention establishes jurisdictions for coastal States, flag States and port States, respectively.

Flag States continue to assume principal responsibility for the safety of navigation and maritime law enforcement. The LOS Convention provides

28 For another example, see Cheng Yan Ki Bonnie, "Implementing Security Council Resolutions in Hong Kong: An Examination of the United Nations Sanctions Ordinance" (2008) 7 (1) Chinese Joumal of International Law 65-98.

2y Russell G. Donaldson, "United Nations resolutions as judicially enforceable in United States domestic courts" (1993) 42 America Law Reports Federal 577.

30 Ibid.

31 Katherine R. Thomas, "The Changing Status of International Law in English Domestic Law" (2006) 53 Netherlands International Law Review 371-398 at 373.

32 Ibid., at 395.

3321 ILM 1261 (1982). Also available at: http://www.un.org/Depts/los/convention_agreements/ texts/unclos/closindx.htm (accessed 26 January 2011). 
that "every State shall effectively exercise its jurisdiction and control in administrative, technical and social matters over ships flying its flag" ${ }^{34}$ It provides that "Every State shall take such measures for ships flying its flag as are necessary to ensure safety at sea with regard, inter alia, to: (a) the construction, equipment and seaworthiness of ships; (b) the manning of ships, labour conditions and the training of crews, taking into account the applicable international instruments; (c) the use of signals, the maintenance of communications and the prevention of collisions" (Art. 94.3). Flag States should ensure compliance by vessels flying their flag or of their registry with applicable international rules and standards and with their laws and regulations and provide for the effective enforcement of such rules, standards, laws and regulations, irrespective of where a violation occurs (Art. 217.1). If a vessel commits a violation of rules and standards, the flag State should provide for immediate investigation and where appropriate institute proceedings in respect of the alleged violation irrespective of where the violation occurred (Art. 217.4). The jurisdiction of the flag State is particularly important for ships navigating on the high seas or in the exclusive economic zone (EEZs). Note that although Article 217 of the LOS Convention bears some general legal implications, they are applicable in particular to the protection and preservation of the marine environment.

A coastal State has sovereignty over its internal and territorial seas, and their superjacent air space. For archipelagic States, sovereignty can be extended to their archipelagic waters. Subject to the rules governing innocent passage in the territorial sea and/or archipelagic waters, the coastal State has the power to inspect any suspected vessel within its territorial waters, particularly under the authorisation of a UNSC Resolution. Coastal States can adopt rules and regulations designating sea lanes and traffic schemes. According to the LOS Convention, a coastal State is entitled to establish the contiguous zone-a sea belt of $12 \mathrm{~nm}$ outward from the outer limit of the territorial sea-for its law enforcement and jurisdiction in respect of preventing and punishing infringement of its customs, fiscal, immigration and sanitary laws and regulations within its territory and territorial sea (Art. 33). Except for the above, in comparison with flag States in respect of jurisdiction over vessels, the regulatory and enforcement power is more limited. ${ }^{35}$ For example, coastal States only

Art. 94 (1) of the LOS Convention.

35 See J. Ashley Roach, "Enforcement of International Rules and Standards of Navigation Safety in the Malacca and Singapore Straits" (1999) 3 Singapore Journal of International or Comparative Law 323-336 at 332. This limitation is partly on account of the attraction of port State control and partly as a reaction to the fear of the risk of unilateral action being unreasonably taken by certain coastal States. See David Anderson, "The Roles of Flag States, 
exercise enforcement powers against ships not entitled to sovereign immunity which cause or threaten to cause major damage to the marine environment of the straits used for international navigation (Art. 233).

The authority for enforcement by the port State was originally designed for marine environmental protection under the LOS Convention, but further development in State practice has demonstrated that port State enforcement authority now extends to cover security matters relating to navigation as well. The first Memorandum on Port State Control adopted in Paris in 1982 (Paris MOU) requires participating shipping authorities in Europe to establish an effective system of port State control with a view to ensuring that these ships meet international safety, security and environmental standards, and that crew members have adequate living and working conditions. ${ }^{36}$ This practice was soon followed by the rest of the world, e.g., the Tokyo MOU, ${ }^{37}$ adopted in December 1993 for the Asia-Pacific region. As regards safery of navigation, port States "may enforce [this] in three separate ways: through the exercise of port state control, by enforcement of MARPOL violation on the high seas, and by judicial enforcement of national laws proscribing conduct in port" ${ }^{38}$ It is reported that the United States successfully prosecuted a major passenger cruise line operating foreign cruise liners out of US ports for making false statements and presenting false records to the US Coast Guard while in US ports. ${ }^{39}$ The port State's empowerment to enforce international rules "amounts to an internationally agreed form of extra-territorial jurisdiction". ${ }^{40}$

The powers of enforcement are exercised by warships, military aircraft, or other governmental service or officially authorised ships and aircraft. In addition to the jurisdiction above, the LOS Convention has established universal jurisdiction for all States over certain crimes at sea, such as piracy and unauthorised broadcasting, and requires States to cooperate on the high seas in enforcement actions regarding illicit traffic in narcotic drugs or psychotropic substances.

Port States, Coastal States and International Organizations in the Enforcement of International Rules and Standards Governing the Safety of Navigation and the Prevention of Pollution from Ships under the UN Convention on the Law of the Sea and Other International Agreements"(1998) 2 Singapore Journal of International \& Comparative Law 557-578 at 577. 36 The text of the MOU is available at: http://www.parismou.org/upload/pdf/MOU\%20 incl. \%2029th\%20Amendment.pdf (accessed 6 December 2007).

${ }_{37}$ The text is available at http://www.tokyo-mou.org/ (accessed 26 January 2011).

38 Roach, op. cit., supra note 35 at 334.

39 Ibid., at 335. For relevant account, see Anderson, op. cit., supra note 35 at 570-571.

40 Anderson, ibid., at 569 . However, as the author states, "There are qualifications: proceedings in respect of discharges into waters within the jurisdiction of another state may be instituted only at the latter's request or that of the flag state or a victim state". Ibid., at 569. 


\section{Use of Force in Maritime Enforcement: Legality, Necessity and Proportionality}

In enforcing UNSC Resolutions, two types of use of force may be involved. One is the direct involvement of the UNSC by directly sending peacekeeping troops or other personnel, such as police, to the region of conflict and the other is the use of force by UN Member States under the authorization of the UNSC.

\section{Use of Force and Self-Defense}

After World War II, the use of force was generally prohibited in international relations. This is expressly stipulated in the Charter of the United Nations, where Article 2(4) provides that "[a]ll members shall refrain in their international relations from the threat or use of force against the territorial integrity and political independence of any state, or in any manner inconsistent with the purposes of the United Nations". The LOS Convention has the same stipulation in its Article 301 on peaceful uses of the seas. The principle of peaceful use of the oceans fundamentally prohibits the use of force at sea.

The Agreement for the Implementation of the Provisions of the United Nations Convention on the Law of the Sea of 10 December 1982 Relating to the Conservation and Management of Straddling Fish Stocks and Highly Migratory Fish Stocks (the 1995 Agreement) applies the principle of restricting the use of force in the arrest of a ship at sea by providing that

[t]he inspecting State shall ensure that its duly authorized inspectors: ...(f) avoid the use of force except when and to the degree necessary to ensure the safety of the inspectors and where the inspectors are obstructed in the execution of their duties. The degree of force used shall not exceed that reasonably required in the circumstances. ${ }^{41}$

Following this principle, States should refrain from the use of force in maritime enforcement actions. None of the Chinese laws and regulations related to the use of the oceans contain stipulations authorizing the use of force against illegal activities within waters under Chinese jurisdiction. The measures China uses are hot pursuit, arrest, detention, and legal proceedings in dealing with illegal activities. Even in bilateral agreements, China prefers

${ }^{41}$ Art. $22(1)(f)$ of the 1995 Agreement. The text is reprinted in 34 ILM 1542 (1995); also available at: http://www.un.org/Depts/los/convention_agreements/convention_overview_fish_ stocks.htm (accessed 21 May 2008). 
adding a provision on the non-use of force. For example, the Fishery Agreement signed between China and Vietnam in December 2000 provides that: "[e]ach party, if it finds that small fishing boats of the other party are conducting fishing activities in its water area in the buffer zone, may send a warning, or take necessary measures to order them to leave that water area, but by so doing that party should restrain its action not to detain or arrest the vessels in question, nor to use force". ${ }^{42}$ (However, one incident occurred against the Chinese position on the use of force in ocean uses, including the fishery management: on 8 January 2005 Chinese maritime police shot and killed 8 Vietnamese in the Gulf of Tonkin. Although China alleged that the dead Vietnamese were "pirates", ${ }^{43}$ Vietnam accused China of seriously violating international law by having killed "innocent" Vietnamese fishermen.) ${ }^{44}$

Nonetheless, while it is generally accepted in international law that the use of force is prohibited, there is an exception in the case of self-defense. According to Article 51 of the UN Charter:

Nothing in the present Charter shall impair the inherent right of individual or collective self-defense if an armed attack occurs against a Member of the United Nations, until the Security Council has taken measures necessary to maintain international peace and security. Measures taken by Members in the exercise of this right of self-defense shall be immediately reported to the Security Council and shall not in any way affect the authority and responsibility of the Security Council under the present Charter to take at any time such action as it deems necessary in order to maintain or restore international peace and security.

This clause recognizes the inherent right of individual or collective self-defense if an armed attack occurs. However, a number of conditions must be fulfilled before a State may resort to the use of force in self-defense. According to Cassese, the following stringent conditions should be imposed:

42 Art. 12 of the Sino-Vietnamese Fishery Agreement. For details, see Zou Keyuan, "SinoVietnamese Fishery Agreement for the Gulf of Tonkin" (2002) 17 (1) International Journal of Marine and Coastal Law 127-148.

43 "Vietnamese Armed Pirating Ships Robbed Chinese Fishing Boats in Beibu Gulf and Shot at Chinese Fishing Boats and Marine Police Patrol Ship in the First Place. The Chinese Marine Police are forced to Shoot Back for Self-Defense. Eight Armed Robbers are Shot Dead and 8 are caught. Weapons and Ammunitions and the Pirating Ship are confiscated", 23 January 2005, available at http://www.fmprc.gov.cn/eng/zxxx/t181176.htm (accessed 21 May 2007). 44 "Vietnam's reaction to the January 8 shooting by Chinese naval patrol police who killed, injured and captured many Vietnamese fishermen and called them "pirates," available at: http://www.mofa.gov.vn/en/tt_baochi/pbnfn/ns050121102026 (accessed 21 May 2007). 
(i) the necessity for forcible reaction had to be instant, overwhelming, leaving no choice of means, and no moment for deliberation;

(ii) the use of force was to be exclusively directed to repel the armed attack of the aggressor State;

(iii) force had to be proportionate;

(iv) the use of force had to be terminated as soon as the aggression had come to an end; and the States acting in self-defense had to comply with the fundamental principles of humanitarian law. ${ }^{45}$

In addition, "armed reprisals in response to small-scale use of force short of an 'armed attack' proper, have been regarded as unlawful both against states and against terrorist organizations". ${ }^{46}$

\section{Jurisprudence of the International Court of Justice}

The conditions on the use of force in self-defense are also expounded by international courts. The International Court of Justice (ICJ) has handled several cases on the legality of the use of force in self-defense. First is the Corfu Channel case in 1949. The ICJ rejected the United Kingdom's statement that its mine-sweeping was a method of self-protection or self-help and declared that the action of the British Navy constituted a violation of Albanian sovereignty. ${ }^{47}$ However, the ICJ also held that the readiness of the British ships to use force if attacked was not an unreasonable precaution, so that the United Kingdom had not violated international law. It indicates that actual recourse to force in self-defense would have been legitimate in the event of an attack. ${ }^{48}$

The ICJ emphasized that the entitlement to resort to self-defense under Article 51 of the UN Charter is subject to the conditions of necessity and proportionality. In Military and Paramilitary Activities in and against Nicaragua (Nicaragua v United States of America), the ICJ held that: "there is a specific rule whereby self-defense would warrant only measures which are proportional to the armed attack and necessary to respond to it, a rule well established in customary international law". ${ }^{49}$

\footnotetext{
45 See Antonio Cassese, "Terrorism is Also Disrupting Some Crucial Legal Categories of International Law" (2001) 12 (5) European Journal of International Law 993-1001 at 995.

46 Ibid., at 996.

47 ICJ, Corfu Channel Case (Merits), Judgment of 9 April 1949, available at: http://www.icj-cij .org/icjwww/idecisions/isummaries/Iccsummary490409.htm (accessed 19 August 2008).

${ }_{48}$ See Stanimir A. Alexandrov, Self-Defense Against the Use of Force in International Law (The Hague: Kluwer Law International, 1996) at 123.

${ }^{49}$ ICJ Reports 1986, p. 94, para. 176; and also in ICJ, Advisory Opinion of 8 July 1996 on "Legality of the Threat or Use of Nuclear Weapons" 35 ILM 814 (1996); also available
} 
In the Legality of the Threat or Use of Nuclear Weapons, a 1996 advisory opinion, the ICJ concluded unanimously that a threat or use of force by means of nuclear weapons that is contrary to Article 2 (4) of the United Nations Charter and that fails to meet all the requirements of Article 51, is unlawful; and a threat or use of nuclear weapons should also be compatible with the requirements of the international law applicable in armed conflict, particularly those of the principles and rules of international humanitarian law, as well as with specific obligations under treaties and other instruments which expressly deal with nuclear weapons. However, the views of the judges were sharply divided and the ICJ finally reached the following decision with the President casting the deciding vote:

It follows from the above-mentioned requirements that the threat or use of nuclear weapons would gencrally be contrary to the rules of international law applicable in armed conflict, and in particular the principles and rules of humanitarian law; However, in view of the current state of international law, and of the elements of fact at its disposal, the Court cannot conclude definitively whether the threat or use of nuclear weapons would be lawful or unlawful in an extreme circumstance of self-defense, in which the very survival of a State would be at stake. $^{50}$

From the above decisions, it can be seen that the ICJ is very cautious in justifying the use of force, even in self-defense. Furthermore, although the ICJ addressed the issue of the threat or use of nuclear weapons, it is apparent that the use of nuclear weapons should be the gravest use of force.

The latest developments in anti-terrorist campaigns around the world may change some conditions on the use of force in self-defense. One reasonable argument is:

where a State is unable or unwilling to assert control over a terrorist organization located in its territory, the State which is a victim of the terrorist attacks would as a last resort be permitted to act in self-defence against the terrorist organization in the State in which it is located..$^{51}$

at: http://www.icj-cij.org/icjwww/idecisions/isummaries/iunanaummary960708.htm (accessed 17 June 2008).

50 Ibid.

51 Elizaberh Wilmshurst, "The Chatham House Principles of International Law on the Use of Force in Self-Defence" (2006) 55 ICLQ963-972 at 970. 
Although it is acknowledged that self-defense against non-State entities "has gained legal currency", ${ }^{52}$ the doctrine of pre-emptive action still remains controversial in international law. ${ }^{53}$

\section{Use of Force under UNSC Authorization}

In addition, a further lawful use of force is envisaged in Article 42, whereby the UNSC may take military enforcement measures in conformity with Chapter VII of the UN Charter, as mentioned above. As military actions include "demonstrations, blockade, and other operations by air, sea or land forces", maritime enforcement, which includes necessary military actions, is crucial to the success of the enforcement of UNSC Resolutions. In this respect, use of force in enforcing UNSC Resolutions becomes a necessity. The authorisation from the UNSC in fact lifts the obligation of any enforcing member State under Article 2(4) of the UN Charter simply because it is requested to act within the mandate of a UNSC Resolution. However, even where force is allowed under a UNSC Resolution, caution and/or restraint should be taken in every step during the enforcement process so as to avoid any abuse of the authorization from the UNSC.

The International Tribunal for the Law of the Sea (ITLOS) in 1999 touched upon the issue of use of force in self-defense in the M/V "Saiga" (No. 2) Case (Saint Vincent and the Grenadines v. Guinea), where the ITLOS expressed a very important view that:

Although the Convention does not contain express provisions on the use of force in the arrest of ships, international law, which is applicable by virtue of article 293 of the Convention, requires that the use of force must be avoided as far as possible and, where force is unavoidable, it must not go beyond what is reasonable and necessary in the circumstances. Considerations of humanity must apply in the law of the sea, as they do in other areas of international law. ${ }^{54}$

Based on the above, the ITLOS found that "Guinea used excessive force and endangered human life before and after boarding the Saiga, and thereby vio-

\footnotetext{
2 Natalino Ronzitti, "The Expanding Law of Self-Defence" (2006) 11 (3) Journal of Conflict o. Security Law 319-342 at 357.

${ }_{53}$ For example, the UN High Level Panel Report, A More Secure World: Our Shared Responsibility, UN Doc. A/59/565, implicitly rejects the concept of pre-emptive action. For comments, see Christine Gray, "A Crisis of Legitimacy for the UN Collective Security System?" (2007) 56 ICLQ 157-170.

${ }^{54}$ See para. 155, Judgment of 1 July 1999, 38 ILM 1323 (1999); also available at: http:// www.itlos.org/start2_en.html (accessed 17 August 2008).
} 
lated the rights of Saint Vincent and the Grenadines under international law".55

On the orher hand, the ITLOS does not totally prohibit the use of force in maritime law enforcement operations. Accordingly, when all efforts have failed, including auditory or visual signals to stop, then firing shots across the bow of the ship may be permitted. In addition, two considerations must be taken into account when force is used: (1) it should be a last resort; and (2) "all efforts should be made to ensure that life is not endangered" ${ }^{56}$ These considerations are applicable where the targeted ship is unarmed. There must be different degrees of using force when an enforcing vessel encounters a pirate ship or a fishing vessel.

The next important question is whether Article 42 of the UN Charter must be expressly cited in a UNSC Resolution in order to justify the use of force in maritime enforcement. Following Iraq's invasion of Kuwait in August 1990 and the imposition of economic sanctions according to UNSC Resolution 661 , a similar legal issue arose as to whether a prior authorisation from the UNSC for a blockade should be required after the United States and the United Kingdom had decided to use warships to enforce UNSC sanctions. ${ }^{57}$ Furthermore, after the adoption of UNSC Resolution 1695, there were divergent views amongst UNSC permanent Members on whether the Resolution authorises non-military or military measures if North Korea launched another missile test. Although the United States took the view that UNSC Resolution 1695 "has a perfectly identical legal effect with that under Chapter VII", China and Russia emphasized that Chapter VII was not referred to in the Resolution. If the Resolution expressly mentions Chapter VII, particularly Article 42, then there should be no controversy over the interpretation of its text. Following this line, when the UNSC decides to take military action against a State that is endangering international peace and security, it is better, and in fact necessary, to expressly invoke Article 42, whereby the UN Member States which enforce the UNSC Resolution can unequivocally use the necessary means of force without controversy.

A related issue is the degree of and extent to which force can be used. UNSC Resolutions usually do not provide guidelines in this regard. For practical purposes, maritime law enforcers under a UNSC Resolution may follow general principles and guidelines derived from the Rules of Engagement and those used for policing. 'Rules of Engagement' "can be defined as the detailed

${ }^{5}$ Para. 159, ibid.

5 See para. 160, ibid.

57 See Nicholas Grief, Public International Law in the Airspace of the High Seas (Dordrecht: Martinus Nijhoff, 1994) at 236. 
guidance given to commanding officers prescribing the circumstances in which they may engage the enemy", and "indicate what constitute[s] hostility and the maximum amount of force which can be used".$^{58}$ It is also reasonably assumed that the rules of naval war, such as the 1907 Convention Relative to Certain Restrictions with Regard to the Exercise of the Right of Capture in Naval War, ${ }^{99}$ could be applicable, in particular when encounters of armed conflict occur during the maritime law enforcement action.

Maritime law enforcement of UNSC Resolutions, although involving military personnel (in particular when police powers are exercised by military authorities), is basically a policing activity at sea. Thus guidelines for policing are applicable. The fundamental principle here is the right to life, as enunciated in the International Covenant on Civil and Political Rights..$^{60}$ The European Convention on Human Rights, while reiterating the above principle, emphasizes that in the use of force, it is no more than "absolutely necessary". ${ }^{61}$ As regards proportionality, the European Commission of Human Rights once held that "regard must be had to the nature of the aim pursued, the dangers to life and limb inherent in the situation, and the degree of the risk that the force employed might result in loss of life". ${ }^{62}$

The United Nations itself has also exerted its efforts in this respect. In December 1979, the UN General Assembly adopted Resolution 34/169 of the Code of Conduct for Law Enforcement Officials, which consists of 8 Articles. It reiterates the important principles of proportionality (force to be used only to the extent required) and necessity (force to be used only when strictly necessary) ${ }^{63}$ In September 1990, the 8 th UN Congress on the Prevention of Crime and the Treatment of Offenders adopted the UN Basic Principles on the Use of Force and Firearms by Law Enforcement Officials. Based on the Code of Conduct, this document further elaborates on its embodied

\footnotetext{
5* Ibid., at 212-213.
}

5y The rext is available at: http://www.dipublico.com.ar/english/treaties/convention-xi-relativeto-certain-restrictions-with-regard-to-the-exercise-of-the-right-of-capture-in-naval-war-thehague-18-october-1907/ (accessed 27 January 2011).

6) Article 6(1) provides that "Every human being has the inherent right to life. This right shall be protected by law. No one shall be arbitrarily deprived of life". 6 ILM 368 (1967).

(1) It lists the following circumstances: (1) in defence of any person from unlawful violence;

(2) in order to effect a lawful arrest or to prevent the escape of a person lawfully detained; and

(3) in action lawfully taken for the purpose of quelling a riot or insurrection. The text is available at: http://www.hri.org/docs/ECHR50.html (accessed 27 January 2011).

62 European Commission of Human Rights, Application No.10044/82: Kathleen Stewart v. $U K$ (10 July 1984, DR. 39/162), cited in Ralph Crawshaw, Barry Devlin and Tom Williamson, Human Rights and Policing: Standards for Good Behaviour and a Strategy for Change (The Hague: Kluwer Law International, 1998) at 97.

6.) Ibid., at 108 . 
26 principles concerning the use of force by law enforcers. Principle 5 stipulates that whenever the use of force and firearms is unavoidable, law enforcement officials should exercise restraint, and act in proportion to the seriousness of the offence and the legitimate objective to be achieved. They are required to minimise damage and injury, and respect and preserve human life. ${ }^{64}$ Although the above two UN documents are only to be seen as "soft law" without legally binding force, they are certainly a source of reference for maritime law enforcement, particularly under UNSC Resolutions. Finally, although it is accepted that maritime law enforcement is similar to policing, it is questionable to argue that "police action" is not considered "uses of force". ${ }^{65}$

One case related to maritime law enforcement and the use of force occurred in the East China Sea. On 22 December 2001, an unidentified ship being pursued in the East China Sea by Japan's Coast Guard for infringing Japan's EEZ sank after being fired on by four Japanese Coast Guard patrol vessels. ${ }^{66}$ All 15 crewmembers on board lost their lives. During the six-hour pursuit, the Japanese vessels fired more than 500 rounds. It is reported that Japan fired the first shot. ${ }^{67}$ Although Japanese law provides that Coast Guard vessels are allowed to fire at, and even sink, ships that do not obey orders in Japan's territorial waters, ${ }^{68}$ there are some conditions on the use of force to the effect that the Coast Guard officers believe that no other means exist to stop a vessel from proceeding, whose crew members, passengers, or other persons do not comply with the repeated orders to stop, and resist the Coast Guard officers' efforts to execute their duties. ${ }^{69}$ In addition, no authorization is granted to the Coast Guard to use weapons against foreign vessels beyond Japan's territorial sea. Thus Japan's use of force to sink the unidentified vessel in China's EEZ finds no basis in its own domestic law. In international law, the LOS Convention does not grant Japan the right to use force against suspicious foreign vessels. Furthermore, a coastal State has no right to arrest a foreign governmental vessel in its territorial sea and EEZ, much less to use force on her. Japan's argument

\footnotetext{
64 Ibid., at 112.

"S See Douglas Guilfoyle, "Interdicting Vessels to Enforce the Common Interest: Maritime Countermeasures and the Use of Force" (2007) 56 ICLQ 69-82 at 79.

${ }_{6}^{6}$ According to some other reports, Japan sent altogether 25 patrol vessels and 14 aircraft to chase the mysterious boat. See Lu Lude, "Japan cannot do as it pleases in China's EEZ", China Ocean News (in Chinese), 8 March 2002.

67 See Peter Landers, "Conflict Shows a Gray Area in Japan Law-Tokyo Weighs Revision to Boost Defense Measures", Asian Wall Street Journal, 26 December 2001, p. 3.

${ }^{68}$ Kazunori Takada, "Japan: Legal issues hang over Japan firing on mystery ship", Reuters English News Service, 27 December 2001.

(9) Art. 20 of Law No. 28 of 27 April 1948 as amended through Law No. 102 of 1999 and Law No. 114 of 2001 (on file with the author).
} 
of self-defense is therefore weak and its actual use of force is excessive under international law. This incident offers some lessons on how a coastal State should conduct maritime law enforcement in an appropriate manner and in strict compliance with the law.

Turning to the issue of North Korea, in contrast to Resolution 1695, Resolution 1718 does mention Chapter VII of the Charter, but limits its application only to use with Article 41, which authorizes the UNSC to employ sanctions, but not involving the use of force. It imposes weapon and financial sanctions on North Korea and authorises UN Member States to inspect cargo to and from North Korea. However, due to opposition by China and Russia, military sanctions are excluded from the sanctions in the Resolution. Ironically, if military action were undertaken against North Korea under the authorisation of the Security Council, North Korea, as a Member of the United Nations, could possibly invoke Article 51 of the UN Charter as an excuse to defend itself, despite its violation of Article 25 of the UN Charter.

Due to the complexity of world politics, difficulties in invoking Chapter VII in order to maintain world peace and security always exist when there are disputes about its invocation. The Korean War is a typical example. The military actions led by the United States under the authorization of the UNSC Resolutions ${ }^{70}$ were viewed by the Chinese as "aggression". Furthermore, China sent its troops to Korea to fight the American-led UN troops. It should be noted that both China (People's Republic of China) and North Korea were not UN Members during that time, and therefore not bound by the UN Charter.

\section{Other Coercive Measures in Maritime Law Enforcement}

Because the use of force is regarded as a last resort, other coercive measures without resorting to the use of force, such as interdiction, search and arrest, and hot pursuit, should be employed first in maritime law enforcement actions.

\section{Interdiction}

In our contemporary world, maritime interdiction, although having a broad as well as a traditional meaning, is mainly carried out now to fight terrorism and other threats to international peace and security. Interdiction is thus

70) Resolutions include S/RES/82, 25 June 1950; S/RES/83, 27 June 1950 and S/RES/84, 7 July 1950. 
embodied in the scheme called the Proliferation Security Initiative (PSI). This is an effort to consider possible collective measures among the participating countries, in accordance with national legal authorities and relevant international law and frameworks, in order to prevent the proliferation of weapons of mass destruction (WMD), missiles and their related materials that pose threats to the peace and stability of the international community. It was first put forward by President Bush on 31 May 2003 during a speech in Krakow, Poland. ${ }^{71}$ The PSI is administered by 11 "core group" countries (Australia, France, Germany, Italy, Japan, the Netherlands, Poland, Portugal, Spain, UK, US), ${ }^{72}$ and later another seven countries joined (Canada, Denmark, New Zealand, Norway, Russia, Singapore, Turkey). As of 2005 , other 46 countries supported it as well. ${ }^{73}$ In September 2003, the United States published the principles of PSI. Accordingly:

The PSI is a broad international partnership of countries which, using their own laws and resources, will coordinate their actions to halt shipments of dangerous technologies to and from states and non-state actors of proliferation concern-at sea, in the air, and on land. The PSI will reinforce, not replace, other non-proliferation mechanisms. Cooperative and coordinated efforts by participating countries will give strength and substance to the broad political consensus against proliferation and help address an increasingly important challenge to international security. The United States is encouraged that all participants have agreed in Paris to abide by these Principles. We support the expansion of PSI to all responsible nations willing to accept the Principles, and will seek the involvement in PSI of such countries. ${ }^{74}$

71 "Remarks by the President to the People of Poland, Wawel Royal Castle, Krakow, Poland, May 31, 2003", available at: http://www.whitehouse.gov/news/releases/2003/05/20030531-3 .html (accessed 29 October 2005) ("When weapons of mass destruction or their components are in transit, we must have the means and authority to seize them. So today I announce a new effort to fight proliferation called the Proliferation Security Initiative. The United States and a number of our close allies, including Poland, have begun working on new agreements to search planes and ships carrying suspect cargo and to seize illegal weapons or missile technologies. Over time, we will extend this partnership as broadly as possible to keep the world's most destructive weapons away from our shores and out of the hands of our common enemies.") For reference, see Douglas Guilfoyle, "Maritime Interdiction of Weapons of Mass Destruction"(2007) 12 (1) Journal of Conflict and Security Law 1-36.

${ }^{72}$ See "The Proliferation Security Initiative (PSI) Maritime Interdiction Exercise hosted by Japan”, 18 October 2004, available at: http:/www.mofa.go.jp/policy/un/disarmament/arms/ psi/exercise-2.html (accessed 11 November 2004).

7.3 J. Ashley Roach, "Proliferation Security Initiative (PSI): Countering Proliferation by Sea", in: Myron H. Nordquist, John Norton Moore and Kuen-chen Fu (eds.) Recent Developments in the Law of the Sea and China (Leiden: Martinus Nijhoff Publishers, 2006) 351-424 at 352.

74 "Statement by the Press Secretary: Principles for the Proliferation Security Initiative", 
Because the core element in the PSI is interdiction, the interdiction principles are also laid out, together with the PSI principles, such that participating States are to:

(1) undertake effective measures, either alone or in concert with other states, for interdicting the transfer or transport of WMD, their delivery systems, and related materials to and from states and non-state actors of proliferation concern;

(2) adopt streamlined procedures for rapid exchange of information concerning suspected proliferation acrivity;

(3) review and work to strengthen their national legal authorities where necessary; and

(4) take specific actions in support of interdiction efforts regarding cargoes of WMD, their delivery systems, or related materials. ${ }^{75}$

Although the PSI does not target any particular country, countries of concern include North Korea, Iran and Syria. PSI raises some issues in international law. The LOS Convention grants the exclusive jurisdiction and control of vessels on the high seas to the flag State, and any search or visit is subject to the permission of the flag State. Exceptions do exist in the LOS Convention, but they are limited to the suppression of piracy, transport of slaves, illicit traffic in narcotic drugs, and unauthorized broadcasting. ${ }^{76}$ Besides, a warship with reasonable grounds may visit a ship without nationality. ${ }^{77}$ As commented: "Article 110 is explicitly exhaustive of the bases for interdiction on the high seas and thus creates a significant legal stumbling block to any assertion of authority to interdict foreign ships and aircraft under the PSI" ${ }^{78}$ Because there is no express rule in international law regarding the interdiction of ships suspected of carrying WMD, Chinese scholars perceive such interdiction on the high seas as a grave destruction of the international legal system and a great downgrade of the dignity of international law. ${ }^{79}$

4 September 2003, available at http://www.state.gov/t/np/rls/prsrl/23809.htm (accessed 29 October 2005).

75 See "Proliferation Security Initiative: Statement of Interdiction Principles", 4 September 2003, available at http://www.state.gov/t/np/rls/prst/23764.htm (accessed 29 October 2005).

${ }^{76}$ See Articles 99-109 of the LOS Convention.

77 See Article 110 (1)(d) of the LOS Convention.

78 Daniel H. Joyner, "The Proliferation Security Initiative: Nonproliferation, Counterproliferation, and International Law" (2005) 30 Yale Journal of International Law 507-548 at 534. 79 See Gao Ying and Sun Bo, "The United States' Proliferation Security Initiative", in: China Association of Arms Control and Disarmament (ed.), 2004 Report on International Arms Control and Disarmament (Beijing: World Knowledge Press, 2004) (in Chinese) at 170. 
In addition to the efforts at the international level, the United States has tried to conclude bilateral agreements to enhance the effectiveness of the implementation of the PSI. For this purpose, the United States signed nonproliferation shipboarding agreements with Liberia (11 February 2004), Panama (12 May 2004) and Marshall Islands (13 August 2004) ${ }^{80}$ According to these agreements, if a ship with either party's flag is suspected of carrying proliferation-related cargo, either party can request the other to confirm the nationality of the ship and if needed, to authorize the boarding, search and possible detention of the ship and its cargo. These agreements, together with PSI partners, cover more than 50 percent of the commercial shipping fleer's dead weight tonnage, which is subject to rapid action consent procedures for boarding, search and seizure by the United States. ${ }^{81}$ It seems that the United States attempted to create a rule of international law through this kind of agreement by shifting its foreign policy "toward a more flexible approach to collective action that eschews both ad hoc unilateralism and institutionalized multilateralism". ${ }^{82}$

As it develops, PSI has been gaining more ground in international law. The first significant document which gives the PSI a kind of legal support is the UNSC Resolution 1540, adopted on 28 April 2004, which provides that "all States shall refrain from providing any form of support to non-State actors that attempt to develop, acquire, manufacture, possess, transport, transfer or use nuclear, chemical or biological weapons and their means of delivery", and the UNSC "calls upon all States, in accordance with their national legal authorities and legislation and consistent with international law, to take cooperative action to prevent illicit trafficking in nuclear, chemical or biological weapons, their means of delivery, and related materials" ${ }^{83}$ However, the Resolution only mentions the "non-State actors", by which it most likely means terrorist groups, but the PSI seems to target some so-called "rogue States" based on the intention of the United States. Furthermore, it is argued that "the text of Operative Paragraph 10 [of UNSC Resolution 1540] does not bestow any additional authority upon states to enforce the PSI and does not exempt states from any international legal obligations they otherwise have" ${ }^{84}$

*0 For the texts of these agreements, see US Department of State, "Ship Boarding Agreements", available at: http://www.state.gov/t/isn/c27733.htm (accessed 27 January 2011).

${ }^{* 1}$ See "US-RMI Agreement: Maritime Security Initiative Signed", 15 August 2004, available at: http://www.yokwe.net (accessed 11 November 2004).

${ }^{82}$ Michael Byers, "Policing the High Seas: The Proliferation Security Initiative" (2004) 98 American Journal of International Law 526-545 at 543.

${ }^{* 3}$ UN Doc. S/RES/1540 (2004), op. cit., supra note 6.

${ }^{44}$ Joyner, op. cit., supra note 78 at 541. 
Although it is debated whether Resolution 1540 has provided some legal basis for the PSI, the amendments made in October 2005 by the Protocol to the 1988 Convention for the Suppression of Unlawful Acts against the Safety of Maritime Navigation (SUA Convention) clearly show the legalization process of the PSI. There are two major revisions/additions: first, the Protocol expands the coverage of the unlawful acts under Article 3 of the SUA Convention by adding a new provision to cover

uses against or on a ship or discharging from a ship any explosive, radioactive material or BCN (biological, chemical, nuclear) weapon in a manner that causes or is likely to cause death or serious injury or damage; discharges, from a ship, oil, liquefied natural gas, or other hazardous or noxious substance, in such quantity or concentration that causes or is likely to cause death or serious injury or damage; uses a ship in a manner that causes death or serious injury or damage; transports on board a ship any explosive or radioactive material, knowing that it is intended to be used to cause, or in a threat to cause, death or serious injury or damage for the purpose of intimidating a population, or compelling a Government or an international organization to do or to abstain from doing any act; transports on board a ship any $\mathrm{BCN}$ weapon, knowing it to be a $\mathrm{BCN}$ weapon; any source material, special fissionable material, or equipment or material especially designed or prepared for the processing, use or production of special fissionable material, knowing that it is intended to be used in a nuclear explosive activity or in any other nuclear activity not under safeguards pursuant to an IAEA comprehensive safeguards agreement; and transports on board a ship any equipment, materials or software or related technology that significantly contributes to the design, manufacture or delivery of a $\mathrm{BCN}$ weapon, with the intention that it will be used for such purpose..$^{85}$

Another major development regarding the ship-boarding regime, initiated by the United States for the implementation of the PSI (as reflected in the bilateral agreements signed between the United States and relevant flag-State countries), has been incorporated into the SUA Convention. According to Article 8 bis of the 2005 Protocol, co-operation and procedures are needed if a State Party desires to board a ship flying the flag of a State Party when the requesting Party has reasonable grounds to suspect that the ship or a person on board the ship is, has been, or is about to be involved in, the commission of an offence under the Convention. The authorization and co-operation of the flag State is required before such a boarding. A State Party may notify the IMO Secretary-General that it would allow authorization to board and search

85 Convention for the Suppression of Unlawful Acts against the Safety of Maritime Navigation, 1988, 27 ILM 672 (1988). The 2005 Protocol is available at: http://www.state.gov/ documents/organization/87452.pdf (accessed 27 January 2011). 
a ship flying its flag, its cargo and persons on board if there is no response from the flag State within four hours. A State Party can also notify that it authorizes a requesting Party to board and search the ship, its cargo and persons on board, and to question the persons on board to determine if an offence has been, or is about to be, committed. The Protocol limits the use of force and includes important safeguarding measures when a State Party takes action against a ship. ${ }^{86}$ Through the above amendments, the controversial boarding regime embodied in the PSI scheme has been legalized under international law through the adoption of the 2005 SUA Protocol, ${ }^{87}$ albeit with modifications and the addition of safeguarding measures to ensure that there is no abuse of this boarding right.

The interdiction principles embodied in the PSI, once legalized, will have ramifications for law of the sea developments and affect the freedom of navigation and overflight.

\section{Interdiction under UNSC Resolution 1718}

Accordingly, UN Member States are authorized to enforce the sanctions listed in the Resolution, including inspection of ships entering or leaving North Korea in order to prevent the proliferation of WMD. China and Russia are concerned that cargo inspection could spark naval confrontations with North Korean vessels and view the cargo check as stated in the Resolution as nonmandatory, but the United States and Japan would like to carry out such inspections under the PSI scheme.

Inspections should be conducted in accordance with international and national law. No international norms currently governing the boarding of a ship in international waters are to be changed by Resolution $1718 .^{88}$ One of these norms is that ships in international waters cannot be boarded without the consent of the flag state. However, when the ship with suspect materials is flying the North Korean flag, it is possible to legally conduct the inspection in accordance with sanctions contained in UNSC Resolution 1718. Furthermore, inspection of North Korean ships can also occur when they enter the port of another state. Note the term the Resolution uses: it is 'inspection' instead of 'interdiction', as the latter is more coercive. The second point is that such inspections are much easier to carry out within the territorial sea than on

86 Ibid.

${ }^{87}$ The Protocol entered into force on 28 July 2010.

8* See Robert Beckman, "North Korea and the UN: Resolution 1718 and Its Legal Dimensions", IDSS Commentaries, 116/2006, 27 October 2006, p. 2; available at: http://www.rsis .edu.sg/publications/Perspective/IDSS1 162006.pdf (accessed 27 January 2011). 
the high seas, due to the difference in maritime jurisdiction. Against the background of the Six-Party Talks, the countries directly involved in the North Korean issue include China, Japan, Russia, South Korea and the United States. They may have the right to make on-board inspections in accordance with UNSC Resolution 1718, although they hold different positions towards North Korea.

After the adoption of the Resolution, North Korea was forced to return to the Six-Party Talks, where in early 2007 it finally agreed to abandon its nuclear weapon project and pledged again to make the Korean Peninsula a nuclear weapon-free zone. The February 13 Agreement freezes North Korea's nuclear program in exchange for the provision to North Korea of 50,000 tons of heavy fuel oil. ${ }^{89}$ In terms of institutional arrangements, the establishment of five working groups, concerning denuclearization of the Korean Peninsula, Northeast Asia peace and security mechanisms, economic and energy cooperation, normalization of DPRK-US relations, and normalization of DPRKJapan relations, respectively, is remarkable. From the Sixth Round of the Talks, whose first session took place in Beijing from 19 to 22 March 2007, the parties involved began to implement in detail the goals set forth in the document entitled "Initial Actions for the Implementation of the Joint Statement", which they had signed in the Fifth Round.

\section{The Korean Peninsula and the 1953 Armistice Agreement}

Although the Six-Party Talks are currently discontinued, China, a key player, has attempted to invite all parties concerned to return to these talks. The 1953 Korean War Armistice Agreement, ${ }^{90}$ signed by the Commander-in-Chief of the United Nations Command and the Supreme Commander of the Korean People's Army and the Commander of the Chinese People's Volunteers, is only an interim agreement for a ceasefire. It is therefore expected that a peace agreement can be reached for Korea. It has been remarked that: "[ $\mathrm{t}]$ he Korean War ended in an armistice. If this separate forum [the Six-Party Talks] does indeed replace the armistice with a permanent peace treaty, then one of the most contentious chapters of the Cold War will be closed."' However, the

${ }^{8 y}$ This agreement is contained in the Joint Statement issued on 13 February 2007. For details, see "Joint Statement: Six Party Talks on N. Korea Nuclear Disarmament", Washington Post, 13 February 2007, available at: http:/www.washingtonpost.com/wp-dyn/content/article/2007/02/ 13/AR2007021300508.html (accessed 5 October 2010).

90 The text of the Agreement is available at http://news.findlaw.com/hdocs $/ \mathrm{docs} / \mathrm{korea} / \mathrm{kwarmagr}$ 072753.html (accessed 7 June 2007).

"John Feffer, "North Korean Nuclear Agreement: Annotated: What It Really Means", 
Armistice Agreement exists largely in a symbolic way at present; therefore any side which resorts to force in and around the Korean Peninsula could be regarded as being in breach of that Agreement. Another contemporary implication of the Agreement may arise from its arrangement to establish the Neutral Nations Supervisory Commission. This mechanism can be borrowed to monitor the maritime law enforcement actions under the UNSC mandate so as to avoid any abusive practice or disproportionate/unnecessary use of force.

\section{Hot Pursuit}

The right of hot pursuit is provided in Article 111 of the LOS Convention. Accordingly, when the coastal State has good reason to believe that a foreign ship has violated its laws and regulations, the hot pursuit of that ship may be undertaken. This pursuit must commence when the foreign ship or one of her boats is within the internal waters, the archipelagic waters, the territorial sea or the contiguous zone of the pursuing State, and may only be continued outside the territorial sea or the contiguous zone if the pursuit has not been interrupted. If the foreign ship is within a contiguous zone, the pursuit may only be undertaken if a violation has occurred of the rights for whose protection the zone was established.

In addition, the right of hot pursuit shall apply mutatis mutandis to violations in the EEZ or on the continental shelf, including the safety zones around continental shelf installations following the applicable laws and regulations of the coastal State in accordance with the LOS Convention.

The LOS Convention in Article 111 sets out conditions for exercising the right of hot pursuit:

(a) The right of hot pursuit ceases as soon as the ship pursued enters the territorial sea of its own State or of a third State.

(b) The pursuit may only be commenced after a visual or auditory signal to stop has been given at a distance which enables it to be seen or heard by the foreign ship.

(c) The right of hot pursuit may be exercised only by warships or military aircraft, or other ships or aircraft clearly marked and identifiable as being on government service and authorized to that effect.

(d) Where a ship has been stopped or arrested outside the territorial sea in circumstances which do not justify the exercise of the right of hot 
pursuit, it shall be compensated for any loss or damage that may have been thereby sustained.

Although the right of hot pursuit is provided in the section on the high seas in the LOS Convention, in East Asia the provision governing this right is placed in the national laws governing the territorial sea and/or the EEZ. ${ }^{92}$ For example, Japan's Law on the Territorial Sea and the Contiguous Zone, promulgated in 1996, provides that the execution of official duties by public officials of Japan in relation to hot pursuit within the internal waters, territorial sea, and the contiguous zone are to be undertaken in accordance with Article 111 of the LOS Convention. ${ }^{93}$

In the M/V "Saiga" (No. 2) Case (Saint Vincent and the Grenadines v. Guinea), Saint Vincent and the Grenadines contended that Guinea did not lawfully exercise the right of hot pursuit under Article 111 of the LOS Convention in arresting the Saiga. Guinea denied that its pursuit was vitiated by any irregularity and maintained that the officers engaged in the pursuit complied with all the requirements set forth in the LOS Convention. ${ }^{94}$ The ITLOS held that "the conditions for the exercise of the right of hot pursuit under Article 111 of the Convention are cumulative; each of them has to be satisfied for the pursuit to be legitimate under the Convention". After having examined the evidence submitted by both sides, the ITLOS found that some of the conditions were not fulfilled, and thus the circumstances under which Guinea stopped and arrested the Saiga on 28 October 1997 did not justify the exercise of the right of hot pursuit in accordance with the LOS Convention. ${ }^{95}$

\section{Final Remarks}

Under UNSC Resolutions, the UN Peacekeeping Operations so far have played a positive, though sometimes ineffective, role in maintaining peace and security in areas of conflict in the world. Since 1945, "UN peacekeepers have undertaken 61 field missions and participated in the implementation of 172

\footnotetext{
y2 For example, it is stipulated in China's Law on the Territorial Sea (Art. 14) and Law on the EEZ (Art. 12).

${ }^{23}$ See Art. 3 and Art. 5 of Japan's Law on the Territorial Sea and the Contiguous Zone. The text is available in Office of Ocean Affairs, Bureau of Ocean and International Environmental and Scientific Affairs, U.S. Department of State, Limits in the Seas, No.120: Straight Baseline and Territorial Sea Claims: Japan, 30 April 1998, at 19-21.

${ }^{44}$ See paras. 139-144, Judgment of 1 July 1999, 38 ILM 1323 (1999); also available at: http://www.itlos.org/start2_en.html (accessed 17 May 2008).

${ }^{4}$ See paras. 146-152, ibid.
} 
peaceful settlements that have ended regional conflicts". ${ }^{96}$ Maritime peace and security is naturally within the mandate of the UN peacekeeping forces. However, this paper addresses an issue which differs from the general peacekeeping operations, namely maritime law enforcement under the authorisation of the UNSC through coercive measures with or without resort to the use of force.

From the above examination, it can be seen that the effectiveness of the maritime law enforcement depends to a large extent on the capacity and determination of the individual enforcing UN Member States on the one hand, and on the close international cooperation among the States, particularly those who take the same position under a UNSC Resolution, on the other.

Recent State practice in military interventions has shown that some States are not satisfied with the existing law on the use of force, but "[o]btaining authorisation by the Security Council before resorting to non-defensive force remains a legal requirement-and not merely a matter of political convenience". ${ }^{97}$ Nevertheless, from the developments regarding the maritime law enforcement of UNSC Resolutions, we can also see the developments of contemporary international law. Something that is legally controversial today may become legally acceptable tomorrow as the law develops. The general trend is: as long as something is beneficial for the interest of the whole mankind it will eventually be accepted by the entire world community.

\% UN Department of Peacekeeping Operations, Fact Sheet, available at: http://www.un.org/ Depts/dpko/factssheet.pdf (accessed 22 March 2008).

97 Tarcisio Gazzini, "The Rules on the Use of Force at the Beginning of the XXI Century" (2006) 11 (3) Journal of Conflict \& Security Law 319-342 at 341. 